\title{
Environmental Protection in Brazil's High Court: safeguarding the environment through a Rule of Law for Nature
}

\author{
A Proteção Ambiental no Superior Tribunal de Justiça: protegendo o meio \\ ambiente por intermédio da operacionalização do Estado de Direito Ecológico
}

\author{
José Rubens Morato Leite \\ Universidade Federal de Santa Catarina - Florianópolis, SC, Brasil \\ Marina Demaria Venâncio \\ Universidade Federal de Santa Catarina - Florianópolis, SC, Brasil
}

\begin{abstract}
Within the context of risk society and its delocalized, incalculable and noncompensable global risks, environmental controversies have become increasingly complex. Within this scenario, the Brazil's High Court (STJ, acronym in Portuguese) stands out as it has been recurrently applying environmental hermeneutics' principles and strategies on its decision-making process and clarifying controversies regarding the interpretation of the environmental legislation. Through bibliographic and jurisprudential research, this article therefore seeks to outline the recent highlights of STJ's case-law, analyzing more in depth some of the court's leading environmental cases and its contributions to the evolution of environmental law in the country.
\end{abstract}

Keywords: Rule of Law for Nature. Brazil's High Court. Case-Law.
Resumo: No contexto da sociedade de risco e de seus deslocalizados incalculáveis e não compensáveis riscos globais, as controvérsias ambientais tornam-se crescentemente complexas. Nesse cenário, o Superior Tribunal de Justiça (STJ) tem se destacado por recorrentemente aplicar estratégias e princípios da hermenêutica jurídica ambiental em seu processo de tomada de decisões, clarificando controvérsias relacionadas à interpretação da legislação ambiental. Nesse sentido, por intermédio da pesquisa bibliográfica e jurisprudencial, este artigo busca enaltecer os destaques recentes da Jurisprudência do STJ, analisando alguns de seus casos emblemáticos e suas contribuições para a evolução do direito ambiental no país.

Palavras-chave: Estado de Direito Ecológico. Superior Tribunal de Justiça. Jurisprudência.

Recebido em: 13/07/2017

Revisado em: 13/08/2017

Aprovado em: 17/11/2017 


\section{Introduction}

In recent decades, an increasing number of environmental lawsuits have been reaching the Brazilian judicial system, which faces the arduous task of giving prompt and adequate responses to intricate environmental controversies, in a context of global risks and complex anthropogenic environmental problems.

Likewise, the failure of traditional rule of law in safeguarding the environment and guaranteeing environmental standards has demanded it to rethink its own fundaments and to adopt legal approaches that are more ecologically centered. The collapse of the system is to some extent given to the fact that environmental law has focused for far too long on achieving human well-being by neglecting a very important element: nature itself. The challenge now is to (re)position it in the center of legal debates, establishing new strategies to tackle environmental law controversies and to achieve a rule of law for nature.

Within this scenario, the Brazilian High Court (known as Superior Court of Justice, STJ in Portuguese), by operationalizing the country's constitutional framework, acknowledging the fundamental right to an ecologically balanced environment and applying environmental hermeneutics' principles and strategies in its decision-making process; has been significantly contributing to the development of environmental law in the country. It has been therefore clarifying issues regarding the interpretation of the environmental legislation.

Therefore, this article aims at outlining recent highlights of STJ's environmental case-law, analyzing more in depth some of the court's leading environmental cases and some of its contributions to the evolution of environmental law in the country.

To achieve that, we first seek to contextualize the issue to the Anthropocene's theory, stressing the urgency of a new rule of law. Additionally, we will give a brief overview of the Brazilian legal framework, focusing on the role of courts and on environmental law principles and hermeneutics related to it. At last, we will outline STJ's 
recent rulings on environmental matters, highlighting their connection to the environmental rule of law for nature.

\section{Rule of Law for Nature and the Anthropocene: initial remarks}

In the $21^{\text {st }}$ century, humanity has become the major driving force shaping our natural world and Planet. The extent and impact of human actions on Earth is so vast that recent studies suggest that "[...] anthropogenic interference will make the initiation of the next ice age impossible over a time period comparable to the duration of previous glacial cycles" (GANOPOLSKI; WINKELMANN; SCHELLNHUBER, 2016). In this context, the term Anthropocene is being adopted by an increasing number of scientists to indicate a new geological era in which the boundaries between the natural and human worlds have become blurred.

Humanity has therefore been living in a time in which the consequences of its actions became unpredictable and difficult to control. According to Purdy (2015, p. 2-3), the most radical expression of this moment is the acknowledgement that the division between the human and natural worlds is no longer precise or useful, once that humanity interferes in everything that surrounds it. There is not a place that remains untouched or that has not been modified by human action (PURDY 2015, p. 3).

Recognizing that we are in the Anthropocene implies in acknowledging that humanity has been, for the past centuries, profoundly interfering in nature, with severe consequences for the environment. Moreover, it implies in acknowledging that shifting towards a more responsible and sustainable development model, committed to the future generations and to nature, is needed.

As stated by the United Nations Environment (UN Environment) (UNEP, 2012, p. 4) GEO-5 Report, global drivers ${ }^{1}$ have been promoting changes of unprecedented scale and rate, leading environmental systems

${ }^{1}$ The term drivers is understood as "the overarching socio-economic forces that exert pressures on the state of the environment" (UNEP, 2012, p. 508). 
to destabilization. Simultaneously, social, economic and environmental problems have become increasingly complex, resulting in more challenges for the emergent risk society. The term risk society is adopted by the sociologist Beck to characterize

[...] an era of modern society that no longer merely casts off traditional ways of life but rather wrestles with the side effects of successful modernization - with precarious biographies and inscrutable threats that affect everybody and against which nobody can adequately insure. (BECK, 2012, p. 8)

In the risk society, industrial society's control mechanisms can no longer properly provide answers and solutions to the so-called global risks, which are mostly delocalized, incalculable and non-compensable. People therefore become members of a global community of threats, which affects the public indiscriminately (BECK, 2012, p. 8).

Within this scenario, environmental law faces many complexities that have been challenging the traditional rule of law (mostly centered in human well-being). Hence, better understanding nature and its fundamental characteristics has become an imperative for the legal science in the Anthropocene, which ought to shift towards a more eco-centric perspective: towards a rule of law for nature, as depicted in Figure 1:

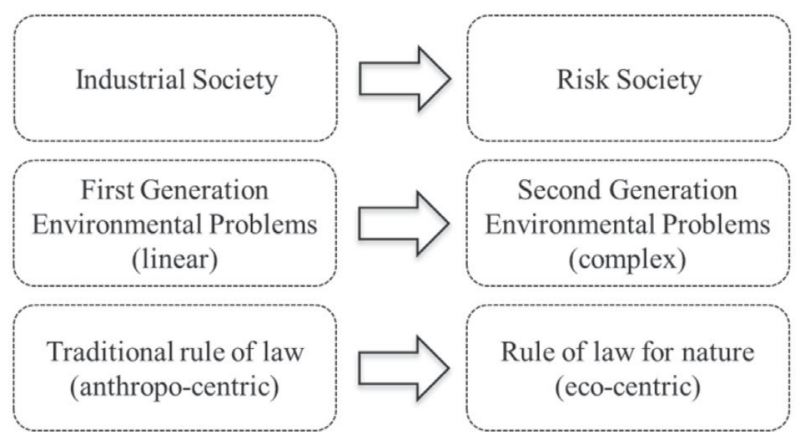

Figure 1: From industrial society to risk society Source: Elaborated by the authors 
As briefly outlined in Figure 1, the transition from industrial to risk society also marks the transition from the first to the second generation of environmental problems. In general, first generation's problems are linked to industrialization, easily recognizable and localized (e.g. illegal coal extraction), whilst the latter are connected to the anthropogenic risk society, have 'hidden' impacts and collateral effects, and are dispersed through the globe (e.g. dangerous climate change). Both generations of problems coexist in the Anthropocene, constituting a rather complex framework of issues that affects indistinctively civil society, political organizations, legal institutions and the world's flora e fauna, threatening the very existence of life on earth.

In that context, increasing legal problems associated with deforestation, flooding, pollution, water and soil contamination, illustrate that environmental law has been playing a rather symbolic role and has not been achieving its full potential to prevent environmental degradation. Nature can no longer be foreseen as an unlimited source of resources, but must be rather understood as a subject of rights with intrinsic value.

An ecological approach to the rule of law therefore "calls for the greening of the entire system of law and governance" (BOSSELMANN, 2013, p. 90). This shift can be exemplified in the concept of an eco-constitutional state in which rule of law and environmental protection are recognized as mutually reinforcing elements of the state (BOSSELMANN, 2013, p. 90).

A rule of law for nature therefore evolves "[...] from the original state-citizen dimension to a system of governance in which all persons, institutions and entities, public and private, including the state itself, are accountable to laws that aim at protecting the health, integrity and security of the environment" (VOIGT, 2013, p. xv). Judges and courts therefore have an important task in the "greening process", as they are responsible for properly applying legal norms and principles to particular cases, through a fair, unbiased and technically-based decision making process.

Environmental problems from the second generation are transboundary, related to uncertainties, interconnected to social and 
economic issues, and often cannot be perceived until their effects become evident (BUGGE, 2013, p. 9-24). Those characteristics challenge the judicial system, which is demanded to provide decisions to complex and intricate environmental controversies.

The emergence of a rule of law for nature thus requires the adoption of an integrative judicial decision making process, guided by environmental law principles. As Bugge (2013, p. 16) points out "[...] we must avoid environmental governance based mainly on a case-bycase application of the law. A case should not be decided on isolation and solely on an individual cost-benefit analysis".

For instance, in Brazil, despite the country being a civil law jurisdiction, judges have been particularly playing an important part in strengthening and improving environmental law, by putting into practice constitutional environmental law principles and developing their interpretation. It is notable that the courts, in special STJ, have been establishing an enhanced method of interpretation for environmental cases, based on environmental hermeneutics' fundaments, providing a greater environmental protection. Highlighting some of these recent developments constitutes the main goal of this research article.

In this sense, the preamble of the World Declaration on the Environmental Rule of Law, which is the outcome document of the International Union for Conservation of Nature (IUCN) first World Environmental Law Congress, recognizes the "[...] rich contribution of environmental law principles to the progressive development of legal and policy regimes for the conservation and sustainable use of nature at all governance levels" (WORLD COMMISSION ON ENVIRONMENTAL LAW, 2016), "[...] observing the essential role that judges and courts play in building the environmental rule of law through the effective application of laws at national, subnational, regional and international levels, and through fair and independent decision-making." (WORLD COMMISSION ON ENVIRONMENTAL LAW, 2016).

The Declaration highlights eleven principles for promoting and achieving environmental justice through the environmental rule of 
law $^{2}$. Namely (1) responsibility to protect nature, (2) right to nature, (3) in dubio pro natura; (4) ecological sustainability and resilience, (5) intragenerational equity, (6) intergenerational equity, (7) gender equity, (8) participation of minority and vulnerable groups, (9) indigenous and tribal peoples, (10) non-regression, and (11) progression.

Those principles and their definitions set an interesting framework to discuss environmental hermeneutics' foundations and their application by the courts, as many of these are also widely recognized and invoked by Brazilian courts. In general, they illustrate the broad scope of matters that concerns to environmental law, and the utmost relevance of analyzing environmental cases through a holistic and integrative perspective.

Overall, a rule of law for nature places nature and its aggregated values in a prominent position of our legal system, demanding special protection and attention in the court ruling-process. Ultimately, there will be no room for human activities if the biophysical limits of our planet are not respected and preserved. This is exemplified in the content of the resilience principle, according to which "[...] the maintenance of a healthy biosphere for nature and humanity should be a primary consideration" (WORLD COMMISSION ON ENVIRONMENTAL LAW, 2016) for judicial decision-making in the Anthropocene.

Having all that in mind, we can now succinctly address the main characteristics of the Brazilian environmental legal framework and environmental hermeneutics, to better comprehend the recent STJ's rulings on environmental matters.

\section{Brazilian Environmental Legal Framework: A brief overview}

Brazil, a civil law country, consists of a federation formed by the indissoluble union of the States, the Municipalities and the Federal District, which have the competence to enact and to establish their own

\footnotetext{
${ }^{2}$ The Declaration understands environmental rule of law "as the application of the rule of law at local, national, regional and international levels in the environmental context" (WORLD COMMISSION ON ENVIRONMENTAL LAW, 2016).
} 
respective laws and policies. These legal instruments must comply with federal legislation and with the constitutional rules and principles.

The current constitution in force, the Brazilian Constitution of 1988, also known as the 'civic constitution' due to the full range of rights and guaranties that it upholds, represented back in 1988 a paradigm shift towards a more democratic regime. It therefore set sovereignty, citizenship, and the dignity of the human person and the political pluralism as the foundations of the Brazilian democratic State, guaranteeing the right of the citizens to more active participation in public life.

Moreover, it also granted unprecedented special protection to the environment, which was declared as a fundamental right: Article. 225 provides that

All have the right to an ecologically balanced environment which is an asset of common use and essential to a healthy quality of life, and both the Government and the community shall have the duty to defend and preserve it of present and future generations ${ }^{3}$.

That implies that all individuals have not only the right to benefit from a well-balanced environment, but also the duty to maintain and safeguard it for posterity. It hence results in a right and a duty of the State of protecting and preserving the environment while developing its executive, legislative and judicial functions.

According to Herman Benjamin (2012, p. 86), many were the consequences for the country's legal system of attributing the characteristic of fundamental human right to the environment, amongst which he highlights the direct applicability of that right and the establishment of a principle of prioritization of the environment over other goods.

'Environment' is understood here in its broad definition as "the set of conditions, laws, influences and interactions of physics, chemistry and

${ }^{3}$ BR const Art. 225. 
biology that permits, shelters and stimulates life in all its forms"4 and is recognized as an autonomous protected legal interest.

It is worthy of notice that although the constitution addresses environmental matters mainly through Title VIII (Social Order), Chapter VI (which includes article 225), there are several other articles in its text related to the subject, such as article 3 (dignity of the human person), article 5 (protection of the right to life and health), article 186 section II (ecological function of property), article 170 (social function of property) and article 182 (urban development policy).

Also, the constitution brings a series of explicit and implicit environmental law principles, amongst which we can underline principles of sustainable development, cooperation, participation, non-regression, in dubio pro natura and precautionary. All of these principles must be observed by the law-making bodies, government agencies and judges in cases in which the environment is concerned. Furthermore, they establish guidelines and set boundaries to the performance of those institutions and agents. The courts in Brazil, for instance, have a relevant constitutional duty of enforcing and adequately interpreting them, seeking a full environmental protection.

Given all that, we can argue in brief that the Brazilian constitutional framework (1) grants an enforceable fundamental right to an ecologically balanced environment, (2) establishes environmental protection as a binding state right and duty, (3) provides a conceptual framework for public policies and (4) assumes strong and distinct judicial protection of the environment (MORATO LEITE; BORATTI, 2015); representing the core of Brazilian Environmental law. Also, it provides fundaments towards the strengthening of rule of law for nature.

There are further legal instruments that are worthy of note such as the Federal Law n. 6,938 of 1981 (National Policy on Environment), Federal Law n. 9,605 of 1998 (Environmental Crimes Law), Federal Law n. 9,985 of 2000 (National Protected Areas System), Federal Law n. 12,187 of 2009 (National Policy on Climate Change), Federal Law

${ }^{4}$ Federal Law No 6,938 1981 art 3 s II . 
n. 12,305 of 2010 (National Policy on Solid Waste) and Federal Law n. 12,651 of 2012 (Forestry Code). These laws, among others ${ }^{5}$, establish at a federal level a set of provisions that grants specific legal protection to several aspects of the environment, elaborating on and implementing the constitutional rights and principles.

\subsection{Decision-Making for a Rule of Law for Nature}

Notwithstanding the many positive aspects of the country's environmental legislation, the wording of environmental laws is often unclear and vague and hence vast controversies concerning their interpretation are common. Furthermore, discussions about whether the environmental rules should prevail over private interests are an equally debated topic.

Within this scenario, Brazilian Courts have been constantly challenged with the task of giving the proper interpretation to the normative commands, which must necessarily be accomplished in consonance with their constitutional duty to safeguard the environment. Due to the wide range of disciplines that are linked to environmental matters, that process has been demanding judges to have a certain level of expertise in fields other than law and a degree of ecological sensibility, that is, to the aspects outlined in the first section of this article.

Judges have certainly a serious responsibility "[...] to stress sustainable development's ecological meaning, in particular in the process of integration of diverse, and often colliding, interests" (VOIGT, 2013). That requires major efforts, and a continuous movement of improving their interpretation and case analyses techniques.

In this sense, the High Court of justice has been demonstrating in its case-law, whose some emblematic decisions are going to be addressed later, successful examples of adoption of environmental rule of law's and hermeneutics' guidelines and principles in its decision making, which has

${ }^{5}$ The full list and text of the Brazilian environmental laws can be found at the Federal Government's website: <http://www4.planalto.gov.br/legislacao>. 
often provided interesting and constitutionally-adequate solutions to the complex controversies arising from the anthropocentric ecological crisis.

Regarding the application of environmental hermeneutics by the judiciary, it in general must be guided by the explicit and implicit principles established by constitutional text (MORATO LEITE; VENÂNCIO, 2015, p. 131), conceding initially a greater relevance to the environment when a collision of interests is verified. It therefore consists in a multidisciplinary approach, which encompasses subjects such as environmental epistemology, justice and ethics; adopting a systemic and teleological perspective for the analysis of environmental law cases (MORATO LEITE; VENÂNCIO, 2015, p. 131)

José Leite and Germana Belchior (2009, p. 74-75) thus argue that in cases in which the fundamental right to the environment collides with other fundamental rights two steps should be followed by the Judiciary, namely the assessment of all the interests, values and private and public goods involved in the collision and the subsequent application of the proportionality principle, granting at first a bigger weight to the environment.

In addition, Herman Benjamin (2014, p. 3-5) proposes that the application of environmental hermeneutics should be mainly guided by some specific subjects, particularly (1) the non-regression principle, (2) the state duty to restore the essential ecological processes, which includes the duty to preserve what exists and the duty to restore what has been damaged, (3) the state duty to preserve biodiversity and genetic resources, (4) the principle of the ecological function of property, and (5) the in dubio pro natura principle.

According to the latter, in case of uncertainty, "[...] matters shall be resolved in a way most likely to favor the protection and conservation of the environment, with preference to be given to alternatives that are least harmful to the environment" (WORLD COMMISSION ON ENVIRONMENTAL LAW, 2016). This principle implies in preventing the undertaking of actions "when their potential adverse impacts on the environment are disproportionate or excessive in relation to the benefits 
derived therefrom" (WORLD COMMISSION ON ENVIRONMENTAL LAW, 2016).

For instance, the STJ supporting the idea of applying environmental hermeneutics to environmental cases in Brazil, understood in the case State Public Prosecutor's Office of Minas Gerais v Pedro Paulo Pereira ${ }^{6}$ that the laws related to the protection of vulnerable groups and diffuse interests - such as the environment - should be interpreted in the way that is most favorable to those groups and diffuse interests. The court thus stipulated on that occasion that the environmental hermeneutics shall be guided by the in dubio pro natura principle, which means that in cases in which there are doubts concerning the interpretation of a given legal command, the interpretation that is most beneficial to the environment shall prevail ${ }^{7}$.

Similarly, in the case Brasilit v State Public Prosecutor's Office of Rio de Janeiro ${ }^{8}$, the Court stated that environmental laws shall meet their intended social purposes and hence be interpreted according to the in dubio pro natura hermeneutic principle.

In short, in recent years the STJ has been applying environmental hermeneutics' principles and strategies to many criminal, administrative and civil law controversies related to the environment, with positive outcomes. Thus, the Court has been contributing to the ability of the State to meet its duty of environmental protection whilst contributing to law enforcement, providing a solid case-law for lower courts and local judges. That depicts that Court' judges are increasingly understanding and properly dealing with the complexity of the transdisciplinary environmental matters. Complex thinking implies in abandoning the linear reasoning, typical from the modernist paradigm, and comprehending the world form a global, non-uniform, perspective.

${ }^{6}$ (Federal) State Public Prosecutor's Office of Minas Gerais v Pedro Paulo Pereira (2012) (STJ).

7 (Federal) State Public Prosecutor's Office of Minas Gerais v Pedro Paulo Pereira (2012) (STJ).

${ }^{8}$ (Federal) Brasilit v State Public Prosecutor's Office of Rio de Janeiro (2013) (STJ). 
Considering that background, we dedicate the next section to the main recent STJ's rulings on environmental matters, stressing emblematic situations in which environmental law principles were properly invoked and used in consonance with a rule of law for nature.

\section{High Court's case law: recent developments and operationali- zation of principles}

STJ is the highest appeal court in Brazil for federal law ${ }^{9}$. Therefore, it has the important attribution of standardizing the interpretation of federal laws within the country's judicial system. The STJ's case-law serves as guidance for the State Courts and local judges, which ought to issue decisions in line with the jurisprudence of the Superior Court.

Disputes regarding civil liability and damage compensation for environmental harms; protected areas and their legal aspects; environmental crimes; and limitations on State agencies authority are just a few of the subjects on which the Court has been delivering decisions.

Although the STJ's case-law concerning environmental issues is vast and diverse, many of the most relevant understandings and opinions in the Court's jurisprudence can be verified in its Environmental Law Theses. The STJ'S Theses Series is a periodical publication elaborated by the Court's Case Law Secretariat and which draws together the major developments in the Court's case law, with each issue focusing on a specific legal theme. The $30^{\text {th }}$ issue addresses environmental concerns and outlines eleven Theses, which can be stated as follows:

$1^{\text {st }}$ Thesis: The simultaneous and cumulative condemnation of the obligations of to do, not to do and to compensate is admitted within the application of the principle of full compensation for environmental damages;

\footnotetext{
${ }^{9}$ The STJ's jurisdiction is set by the art. 105 of the Brazilian Federal Constitution of 1988 and includes not only cases concerning federal law controversies (non-constitutional), but also its original jurisdiction lawsuits, e.g. those related to the conflict of jurisdiction between two State Courts.
} 
a) 2 $2^{\text {nd }}$ Thesis: The Brazilian Institute of Environment and Renewable Natural Resources ${ }^{10} \quad$ (IBAMA, acronym in Portuguese) cannot impose administrative sanctions other than those expressly provided by law.

b) $3^{\text {rd }}$ Thesis: There is no vested right to pollute or to degrade the environment and the Brazilian legislation does not allow a landholder to continue with ongoing practices prohibited by law.

c) E.g. the owner of an environmental license may have her or his right revoked or modified if the conditions upon which the license was granted change significantly and the licensed activity or property starts to harm the environment.

d) $4^{\text {th }}$ Thesis: The precautionary principle requires the reversal of the evidentiary burden of proof; therefore, the person who supposedly caused the environmental damage shall either prove that he or she was not responsible for it or that the substance released to the environment is not likely to harm it.

e) $5^{\text {th }}$ Thesis: The IBAMA cannot impose sanctions for criminal offences, which are Courts' jurisdiction.

f) $6^{\text {th }}$ Thesis: The use of fire in agro-pastoral and forestry practices requires prior authorization issued by the State.

g) $7^{\text {th }}$ Thesis: Those responsible for environmental degradation are jointly and severally liable, and the law determines as a rule the permissive joinder of parties in class or collective actions.

h) $8^{\text {th }}$ Thesis: In regard to environmental protection, the State is civilly liable when its omission(s) in the exercise of its supervising duty represent a relevant circumstance for the occurrence or aggravation of the environmental damage.

i) $9^{\text {th }}$ Thesis: The owner of immovable property has an obligation to remedy any environmental degradation or damage inflicted on it, even if he or she did not give cause it, given the propter rem nature of environmental damages.

\footnotetext{
${ }^{10}$ IBAMA is a government agency linked to the Brazilian Ministry of Environment (MMA, acronym in Portuguese) responsible for overseeing the environment and conducting the environmental licensing and other administrative procedures, amongst other activities.
} 
j) $10^{\text {th }}$ Thesis: The liability for environmental damage is strict, according to the theory of integral risk, therefore a company responsible for environmental damage cannot argue reasons for exclusion of civil liability in its defense.

k) $11^{\text {th }}$ Thesis: The Public Administration has five years to enforce the fine related to environmental infractions, to be counted from the end of the administrative proceeding that stablished it.

It is important to have in mind that the STJ's Environmental Theses are the result of reiterated decisions on the same matter, where a similar reasoning was applied. Also, they represent an adoption of avant-guard positions by the court, which has often been issuing decisions aligned with the idea of achieving a full environmental protection, safeguarding public interests in detriment of the private (e.g. tenth thesis). These decisions somewhat meet the challenge of achieving a greener system at a judicial level, as they operationalize our constitutional framework and standardize the interpretation of core environmental principles and legal commands, which are recurrently neglected and/or misinterpreted by other judicial instances.

An example of a principle that had been mitigated for a considerable time is the principle of full compensation for environmental damages. It was previously understood that in face of a given environmental damage, the defendant could not be simultaneously condemned to repair it (to do obligation), to abstain from doing the activity that generated the damage (not to do obligation) and to pay a fine due to the harmful activity or act (obligation to compensate). That was also the predominant opinion of the STJ on the matter until it applied environmental hermeneutics' approaches to related cases, starting to understand the environment as a fundamental right and consequently the existence of an obligation to fully repair all damages inflicted to it, which comprises obligations to do, not to do and to compensate. Henceforth, the same understanding has been widely recognized and utilized by the state courts.

At last, as we previously pointed out, the Theses do not bind the state courts and local judges. Nonetheless, they are important guidelines to support their decision-making processes in regard to the environmental 
disputes. Moreover, they represent the development and the consolidation of more refined interpretation techniques for the environmental legislation within the country's High Court. The full study of the reasoning process behind the cases that resulted in the Theses, however, is not subject of that succinct article. Nevertheless, we would like to briefly analyze more in depth two representative principles and some of their related-cases, which provide, in our understanding, good examples of the alignment of the Court with the emergent rule of law for nature.

\subsection{Precautionary Principle}

The precautionary principle is widely recognized in Brazilian jurisprudence, although courts and judges not always reach a consensus regarding its extent. According to the Rio Declaration, in cases in which "[...] there are threats of serious or irreversible damage, lack of full scientific certainty shall not be used as a reason for postponing costeffective measures to prevent environmental degradation" (UN, 1992). That always provided fuel for an extensive debate on whether the application of the principle should be done in a flexible or strict manner, under the argument that the latter could halt the development of economic activities.

Not having the intent of extending here the debates around the topic, we would like to concisely point out that it is rather clear "that rule of law for nature implies a strict interpretation and implementation of the precautionary principle. It requires that law is 'organic' and flexible so as to meet changing circumstances and new insight" (Bugge 2013, 11). In this sense, understanding the right to an ecologically balanced environment as one of the core values of our legal system, to some extent implies in being increasingly strict with permits and licenses given to potentially harmful activities which cannot scientifically prove their safety. That issue relates to the debates regarding genetically modified organisms, pesticides and even radio stations.

For instance, in the case Maxtel S.A v. Federal Public Prossecutor's Office $^{11}$, the STJ invoked the precautionary principle to prevent the

${ }^{11}$ (Federal) Maxitel S.A v. Federal Public Prosecutor's Office (2016) (STJ). 
installation of a radio station. According to the Court "Having in mind the lack of scientific certainty regarding the effects that the installation of the radio station might cause to human health, the protection of the environment prevails in consonance to the precautionary principle" 12 . Also, the fourth thesis, regarding the inversion of the evidentiary burden of proof, portrays a stricter application of the precautionary principle. Accordingly, both cases depict a tendency towards an ecological approach in the Court, and consequently, room for a more rigorous application of the principle.

\subsection{Sustainable Development Principle}

The principle of sustainable development, on the other hand, has only recently started to be invoked by the STJ. It in general concerns to the maintenance of a healthy environment whilst developing the many natural, social, cultural and economic aspects connected to it, for the present and future generations. Moreover, it also implies in respecting earth's biophysical limits, in consonance with the idea of a strong sustainability.

The emblematic cases related to its application are related to the interpretation of article 54 of the Environmental Law Crimes Act ${ }^{13}$, which is related to the crime of polluting the environment in any forms or levels that result, or may result, in damages to human health, animals, or nature.

The court has been thus invoking the principle to conclude that the mere possibility of causing damage constitutes an offence under the law, although the article does not explicitly state so. In this sense, the court ruled in the Case Federal Public Prosecutor's Office v. Edegar Antônio Castegnaro $^{14}$ that

\footnotetext{
${ }^{12}$ From the original in Portuguese: "Tendo em vista a ausência de certeza científica quanto aos efeitos que a instalação de estação rádio-base pode causar à saúde humana, prevalece a defesa do meio ambiente em atendimento ao princípio da precaução".

${ }^{13}$ Federal Law n. 9,605 1998 art. 54.

${ }^{14}$ (Federal) Federal Public Prosecutor’s Office v. Edegar Antônio Castegnaro (2014) (STJ).
} 
The principles of sustainable development and prevention set by the art. 225 of the Federal Constitution, should guide the interpretation of environmental laws, whether they are administrative or criminal, once that the environment is a patrimony to this generation and the ones to come, as well as fundamental right, which should result in cautious conducts, avoiding the risk of causing damage, even if potential, to the environment ${ }^{15}$.

The court also manifested a similar understanding in the case Jose Elias Silva Torres v. State Public Prosecutor's Office of Amazonas ${ }^{16}$. We hence observe that the judicial recognition of a sustainable development principle illustrates that the Judiciary is increasingly 'sensible' to some implications of the rule of law of nature, namely stressing the meaning of sustainability and integrating it to its decision making, assuming a compromise with the intra and intergenerational equity.

\section{Conclusion}

Overall, we observed that environmental law is faced in the Anthropocene with many great challenges that demand legal scholars to revisit its very own foundations. An emerging rule of law for nature therefore calls for the greening of all governance levels and for the achievement of a balance between the values 'human wellbeing' and 'nature'. In the judicial sphere, that implies in the need for more technically qualified judges that comprehend the complexity of environmental issues, the adoption of adequate interpretation techniques, in consonance with environmental hermeneutics' principles and strategies,

${ }^{15}$ From the original in Portuguese: "Os princípios do desenvolvimento sustentável e da prevenção, previstos no art. 225, da Constituição da República, devem orientar a interpretação das leis, tanto no direito ambiental, no que tange à matéria administrativa, quanto no direito penal, porquanto o meio ambiente é um patrimônio para essa geração e para as futuras, bem como direito fundamental, ensejando a adoção de condutas cautelosas, que evitem ao máximo possível o risco de dano, ainda que potencial, ao meio ambiente".

${ }^{16}$ (Federal) Jose Elias Silva Torres v. State Public Prosecutor's Office of Amazonas (2016) (STJ) 
and the true operationalization of the country's constitutional framework, which already grants a remarkable protection to the environment.

In that context, STJ has been recurrently applying a refined legal expertise to the environment-related cases, understanding that they must follow a logic other than the one applied to the ordinary criminal, administrative and civil cases. Hence, the Court has been contributing to putting an end to environmental controversies that have been originating divergent decisions not only in the state courts but also in the local Judiciary. These recent developments in the Court's case-law offer a fresh contribution to the debates regarding legal mechanisms for a greater environmental protection, regarding a rule of law that not only has the environment as one of its core values but also that foresees the relationship environment-society through a global and integrative perspective.

In conclusion, Brazil's judiciary is going through a remarkable path of improving its comprehension of environmental issues and legislation, and as part of this the STJ is playing an important part in clarifying major controversies, helping to overcome one of the main challenges regarding Brazil's environmental legislation, that is, its proper interpretation. Its recently released Environmental Law Theses brought together important ecologically-based court's rulings, offering a tool to assist judicial decision making on the respective matters. It is certain that much still must be done in tackling Brazil's great environmental issues, but these recent improvements in case law certainly depict that we are heading towards a more effective application of the environmental legislation by the Judiciary.

\section{References}

BECK, Ulrich. World at Risk. Cambridge: Polity Press, 2012.

BENJAMIN, Antonio Herman de Vasconcellos e. Hermenêutica do Novo Código Florestal. Revista de Direito Ambiental, [S.l.], p. 1-9, 2014. 
BENJAMIN, Antonio Herman. Constitucionalização do ambiente e ecologização da Constituição Brasileira. In: CANOTILHO, Joaquim Gomes; MORATO LEITE, José Rubens. Direito Constitucional Ambiental Brasileiro. São Paulo: Saraiva, 2012. p. 83-156.

BOSSELMANN, Klaus. Grounding the rule of law. In: BOSSELMANN, Klays. Rule of law for nature: new dimensions and ideas in environmental law. Cambridge: Cambridge University Press, 2013. p. 75-93.

BUGGE, Hans Christian. Twelve fundamental challenges in environmental law: an introduction to the concept of rule of law for nature. In: VOIGT, Christina. Rule of law for nature: new dimensions and ideas in environmental law. Cambridge: Cambridge University Press, 2013. p. 3-26.

GANOPOLSKI, Andrey; WINKELMANN, Ricarda;

SCHELLNHUBER, Joachim. Critical insolation-CO2 relation for diagnosing past and future glacial inception. Nature, January 2016.

MORATO LEITE, José Rubens, and Germana Belchior. Estado de direito ambiental: uma análise da recente jurisprudência ambiental do STJ sob o enfoque da hermenêutica jurídica. Revista de Direito Ambiental, [S.l.], v. 56, p. 55-92, 2009.

MORATO LEITE, José Rubens; BORATTI, Larissa. Constitutional Environmental Protection in Brazil: Context, Legal Design and Jurisprudence (Protected Areas). 7TH GERMAN-BRAZILIAN SYMPOSIUM. Heidelberg, 2015. Anais.. 2015.

MORATO LEITE, José Rubens; VENÂNCIO, Marina Demaria. Hermenêutica jurídica para o século XXI. In: MORATO LEITE, José Rubens; IGLECIAS, Patrícia Faga. Direito ambiental para o século XXI. São Paulo: Editora Revista dos Tribunais, 2015. p. 121-141.

PURDY, Jedediah. After nature: A politics for the Anthropocene. Cambridge: Harvard Universtiy Press, 2015.

SUPERIOR TRIBUNAL DE JUSTIÇA. Edição n. 30: Direito Ambiental. March 18, 2015. Disponível em: <http://www.stj.jus. 
$\mathrm{br} / \mathrm{SCON} / \mathrm{jt} /$ toc.jsp?edicao=EDI $\% \mathrm{C} 7 \% \mathrm{C} 3 \mathrm{O} \% 20 \mathrm{~N} . \% 2030: \% 20$ DIREITO\%20AMBIENTAL>. Access in: December 15, 2015.

UN. Rio Declaration on Environment and Development. Rio de Janeiro, 1992.

UNEP. Global Environment Outlook (GEO5). Velleta, 2012.

VOIGT, Christina. Preface. In: VOIGT, Christina. Rule of law for nature: new dimensions and ideas in environmental law, Cambridge: Cambridge, 2013. p. XIII-XVII.

VOIGT, Christina. The principle of sustainable development: integration and ecological integrity. In: VOIGT, Christina. Rule of law for nature: new dimensions and ideas in environmental law, Cambridge: Cambridge, 2013. p. 146-157.

WORLD Commission on Environmental Law. World Declaration on the Environmental Rule of Law. Rio de Janeiro: April, 2016.

José Rubens Morato Leite: Professor at the Faculty of Law of the Federal University of Santa Catarina, Brazil; PhD at the Federal University of Santa Catarina, Brazil; member of the IUCN Academy of Environmental Law Governing Board; president of the Law for a Green Planet Institute.

E-mail:morato.1@ufsc.br.

Address: Sala 318, Centro de Ciências Jurídicas, Campus Reitor João David Ferreira Lima - UFSC, Trindade, Florianópolis, Santa Catarina, Brazil. CEP: 88040-900.

Marina Demaria Venâncio: Doctoral Student at the Federal University of Santa Catarina, Brazil; Master's Degree from the Faculty of Law of the Federal University of Santa Catarina, Brazil; member of the Early Career Group of the World Commission on Environmental Law, IUCN.

E-mail: marina.venancio@posgrad.ufsc.br.

Address: Universidade Federal de Santa Catarina, Centro de Ciências Jurídicas. Florianópolis, SC, Brasil. CEP: 88040-900. 
